\title{
Influence of enzyme and probiotic supplementation on growth performance and gut health of broiler chicken
}

\author{
Agboola, A. F. ${ }^{1 \star}$, Omidiwura, B. R. $0 .{ }^{1}$, Ahmed, R. $0 .{ }^{2}$, Soneye, V. F. ${ }^{1}$ and Majolagbe, H. $0 .{ }^{3}$ \\ 1Department of Animal Science, University of Ibadan, Ibadan, Nigeria. \\ ${ }^{2}$ Department of Animal and Avian Sciences, University of Maryland, College Park, USA. \\ ${ }^{3}$ Adeniran Ogunsanya College of Education, Otto/ljanikin, Lagos state, Nigeria. \\ *Corresponding author. Email: adebisi.agboola@gmail.com; Tel: +234 8022004830.
}

Copyright (C) 2021 Agboola et al. This article remains permanently open access under the terms of the Creative Commons Attribution License 4.0, which permits unrestricted use, distribution, and reproduction in any medium, provided the original work is properly cited.

Received 1st February, 2021; Accepted 19th February, 2021

\begin{abstract}
This study was carried out to investigate the effects of enzyme, probiotic or their combinations on growth response, microbiota and gut histopathological indices of broiler chicken. One hundred and fifty (150) one-day old unsexed Arbor Acre broiler chicks were weighed and randomly allotted to 5 dietary treatments; each diet had 5 replicates of 6 birds each in the study that lasted for 42 days. Treatment 1 consists of the basal diet (negative control; NC): Treatment 2 was $\mathrm{NC}+0.1 \%$ antibiotic (positive control), Treatment 3: $\mathrm{NC}+0.4 \%$ probiotic, Treatment 4: $\mathrm{NC}+0.1 \%$ enzyme and Treatment 5 : $\mathrm{NC}+0.4 \%$ probiotic $+0.1 \%$ enzyme. Performance indices were measured. On day 42 , ileal digesta was collected from two birds per replicate for microbial count while about $5 \mathrm{~cm}$ of distal ileum was severed for histopathology. The results showed that diets had no significant $(p>0.05)$ effect on the performance of birds at the starter and finisher phases. Total heterotrophic counts of birds fed with basal and probiotic diets were similar but significantly $(p<0.05)$ higher than other diets. The highest Lactobacilli count was recorded in the mixture of probiotic + enzyme diet while least was observed in probiotic $\left(2.58 \times 10^{5} \mathrm{cfu} / \mathrm{ml}\right)$ and enzyme supplemented diets $\left(1.45 \times 10^{5} \mathrm{cfu} / \mathrm{ml}\right)$. Total coliform count of birds fed antibiotic diet was significantly $(p<0.05)$ lower $\left(14.12 \times 10^{5} \mathrm{cfu} / \mathrm{ml}\right)$ than for those on other diets. Total Escherichia coli count was highest in birds fed antibiotic while least was observed in birds fed mixture of probiotics + enzyme diet. Photomicrographs of the ileum of birds fed basal diet showed sloughed mucosa layer and degenerated villi. However birds fed antibiotic, probiotic, enzyme or probiotic+enzyme diets showed normal mucosa layer with normal villi, the lamina proprial showed normal tissues with mild infiltrate. In conclusion, feed supplements used in this study can serve as viable alternatives to antibiotics in broiler nutrition without compromising birds' health.
\end{abstract}

Keywords: Broilers, feed additives, growth response, histology.

\section{INTRODUCTION}

Concerns about the potential development of antimicrobial resistance and about transference of antibiotic resistance genes from animal to human microbiota led to the ban of antibiotics as growth promoters in poultry production (Mathur and Singh, 2005; Stanton, 2013). The National Agency for Food and Drug Administration and Control in Nigeria, has banned the use of antibiotics as a growth promoter and as a preventive measure for mould proliferation in animal feed (NAFDAC, 2018). As a result, it became necessary to seek for viable alternatives that could enhance the natural defense mechanisms of animals and reduce the massive use of antibiotics. Alternatives like prebiotics (Heidarpour et al., 2011), synbiotics (Agboola et al., 2014), organic acids (Fernandes et al., 2014), phytobiotics (Gheisar and Kim, 2017), plant extracts (Kurekci et al., 2014), acidifiers (Markazi et al., 2019), etc. have been found to play an important role in improving growth performance, maintaining microbial balance and enhancing gut integrity in poultry (Hosseini et al., 2016).

Probiotics are live microbial feed supplement that beneficially affect the host animal by improving its microbial intestinal balance (Fuller, 1989; Bidarkar et al., 2014). They improve a positive balance of the population of useful microbes in the intestinal flora by antagonistic action through the secretion of their metabolites such as 
bacteriocins, organic acids and hydrogen peroxide. In-feed enzymes are produced as fermentation products fromfungi and bacteria and help to break down certain components of the feed, such as non-starch polysaccharides (NSPs) and phytates, which are indigestible by the endogenous enzymes produced by birds (Khattak et al., 2006). Enzyme, break down the NSPs, decreases intestinal viscosity and eventually improve the digestibility of nutrients, thus, improving the gut integrity. It was therefore the objective of this study to determine the effect of dietary supplementation of probiotic, enzyme or their combination on growth response, intestinal microbial load and histopathological indices of broiler chicken.

\section{MATERIALS AND METHODS}

\section{Experimental site}

This study was carried out at the poultry research unit of Teaching and Research Farm, University of Ibadan, Nigeria. The research site is situated geographically on the South-west zone of Nigeria.

\section{Management of experimental birds}

One hundred and fifty (150) one-day old unsexed Abor acre broiler chicks were used for the study. They were purchased from a reputable commercial hatchery farm in Ibadan, Oyo state. They were weighed, tagged and randomly allotted to 5 diets in a completely randomized design. Each diet had 5 replicates with 6 birds per pen and reared in two phases (starter phase, 0-21 and finisher phase, 22-42). Treatment 1 consists of the basal diet (negative control; NC): Treatment 2 was $\mathrm{NC}+0.1 \%$ antibiotic \{oxytetracyclin\} (positive control; PC), Treatment 3: $\mathrm{NC}+0.4 \%$ probiotic \{Lactobacillus acidophilus + Saccharomyces cerevisiae\}, Treatment 4: $\mathrm{NC}+0.1 \%$ enzyme $\{\beta$-glucanase, phytase and organic acids $\}$ and Treatment 5: $\mathrm{NC}+0.4 \%$ probiotic $+0.1 \%$ enzyme. Experimental diets for starter phase (Table 1) and finisher phase (Table 2) were formulated to meet the nutrient requirements of the birds according to the recommendation of NRC (1994).

\section{Data collection}

\section{Performance indices}

Feed intake was calculated as difference between amounts given and left over. The birds were weighed at the end of the starter and finisher phases and values were used to calculate body weight gain and feed conversion ratio.

\section{Microbial analysis}

On day 42, two birds per replicate were sacrificed and dissected and the digestive tracts were carefully excised. Digesta sample was harvested from two-third of ileal section between Meckel diverticum and lleo-caeco-colonic junction pooled according to replicates and frozen for further analysis. The digesta were mixed in a $10 \mathrm{ml}$ prereduced salt medium (Holdeman et al., 1977) and serially diluted according to the procedure described by Engberg et al. (2004) to examine the count of Lactobacilli (Rogosa, CM 0627, incubated anaerobically 48 hours) and coliforms (Mackonkey, CM 0115, incubated aerobically 24 hours). Gut tissue sample was serially diluted from $10^{-7}$ to $10^{-3}$. From each dilution, $0.1 \mathrm{ml}$ of the sample was plated onto the appropriate media. After incubation period of 48 hours, the plates were observed for bacterial growth and colonies were counted. While the MRS plates were kept anaerobically in an anaerobic jar at a temperature $35^{\circ} \mathrm{C}$ for 48 hours. After 48 hours, the plates were observed for bacteria and colonies were counted.

\section{Histopathological parameters}

At the end of 6 weeks of the experiment, two birds from each replicate were selected and weighed. The birds were slaughtered and the digestive tracts were carefully excised. Intestinal samples were removed and then transferred into specimen bottles containing $10 \%$ formalin where normal hematoxylin and eosin standard procedures were performed according to the methods of lji et al. (2001).

\section{Proximate analysis}

The proximate composition of the diets was determined according to the methods of AOAC (2000).

\section{Statistical analysis}

Data obtained were analyzed using ANOVA of statistical analysis system, SAS (2012). Means were separated using Duncan's multiple range test and tested at $p=0.05$ level of significance. The statistical design was:

$Y i j=\mu+t_{i}+e_{i j} ;$

Where $Y_{i j}$ for example, is the performance indices measured, $\mu$ is the overall mean, $t_{i}$ is the fixed effect of the treatments, and $e_{i j}$ is the random error.

\section{RESULTS}

Performance of broiler chickens fed diets supplemented with probiotic and enzyme at starter phase (0-21days) and finisher phase (22-42 days)

The results on the performance of birds at the starter and finisher phases are presented in Table 3. There were no 
Table 1. Gross composition ( $\mathrm{g} / \mathrm{kg})$ of diets supplemented with probiotic and enzyme (starter phase).

\begin{tabular}{|c|c|c|c|c|c|}
\hline Ingredient & $\begin{array}{l}\text { Negative control } \\
\text { (NC) Basal diet }\end{array}$ & $\begin{array}{l}\text { Positive control } \\
\text { (PC) Antibiotic }\end{array}$ & $\begin{array}{c}\mathrm{NC}+ \\
\text { Probiotic }\end{array}$ & $\begin{array}{c}\mathrm{NC}+ \\
\text { Enzyme }\end{array}$ & $\begin{array}{c}\mathrm{NC}+\text { Probiotic }+ \\
\text { Enzyme }\end{array}$ \\
\hline Corn & 566.00 & 565.00 & 562.00 & 565.00 & 561.00 \\
\hline Soyabean meal & 370.00 & 370.00 & 370.00 & 370.00 & 370.00 \\
\hline fish meal & 30.00 & 30.00 & 30.00 & 30.00 & 30.00 \\
\hline Soya Oil & 8.00 & 8.00 & 8.00 & 8.00 & 8.00 \\
\hline Dicalcium phosphate & 16.00 & 16.00 & 16.00 & 16.00 & 16.00 \\
\hline Broiler Premix & 2.00 & 2.00 & 2.00 & 2.00 & 2.00 \\
\hline Limestone & 4.00 & 4.00 & 4.00 & 4.00 & 4.00 \\
\hline Methionine & 1.00 & 1.00 & 1.00 & 1.00 & 1.00 \\
\hline Lysine & 1.00 & 1.00 & 1.00 & 1.00 & 1.00 \\
\hline Table Salt & 2.00 & 2.00 & 2.00 & 2.00 & 2.00 \\
\hline Antibiotic & 0.00 & 1.00 & 0.00 & 0.00 & 0.00 \\
\hline Probiotic & 0.00 & 0.00 & 4.00 & 0.00 & 4.00 \\
\hline Enzyme & 0.00 & 0.00 & 0.00 & 1.00 & 1.00 \\
\hline TOTAL & 1000.00 & 1000.00 & 1000.00 & 1000.00 & 1000.00 \\
\hline \multicolumn{6}{|c|}{ Calculated nutrient $(\mathrm{g} / \mathrm{kg})$} \\
\hline Crude protein & 233.78 & 233.68 & 233.38 & 233.68 & 233.28 \\
\hline Energy $\mathrm{ME}, \mathrm{kcal} / \mathrm{kg}$ & 3095.64 & 3092.21 & 3081.9 & 3092.21 & 3078.47 \\
\hline Ether extract & 44.94 & 44.90 & 44.78 & 44.90 & 44.90 \\
\hline crude fibre & 38.56 & 38.54 & 38.47 & 38.54 & 38.54 \\
\hline Calcium & 7.72 & 7.72 & 7.72 & 7.72 & 7.72 \\
\hline Total phosphorus & 7.51 & 7.50 & 7.50 & 7.50 & 7.50 \\
\hline Non-phytate P & 4.10 & 4.10 & 4.10 & 4.10 & 4.10 \\
\hline Ca:NPP & 1.88 & 1.88 & 1.88 & 1.88 & 1.88 \\
\hline
\end{tabular}

Supplied the following per kg diet: vitamin $A, 12500 \mathrm{IU}$; vitamin $\mathrm{D}_{3}, 2500 \mathrm{IU}$; vitamin $\mathrm{E}, 40 \mathrm{mg}$; vitamin $\mathrm{K}_{3}$, 2mg; vitamin $\mathrm{B}_{1}$, 3mg; vitamin $\mathrm{B}_{2}, 5.5 \mathrm{mg}$; niacin, $55 \mathrm{mg}$; calcium panthotenate, $11.5 \mathrm{mg}$; vitamin $\mathrm{B}_{6}, 5 \mathrm{mg}$; vitamin $\mathrm{B} 12,0.025 \mathrm{mg}$; choline chloride, $500 \mathrm{mg}$; folic acid, $1 \mathrm{mg}$; biotin, $0.08 \mathrm{mg}$; manganese, 120mg; Iron, 100mg; zinc, 80mg; copper, $8.5 \mathrm{mg}$; iodine, $1.5 \mathrm{mg}$; cobalt, 0.3mg; selenium, 0.12mg; anti-oxidant, $120 \mathrm{mg}$.

significant differences observed in the final weight, feed intake, weight gain, and feed conversion ratio of birds on the dietary treatments.

\section{Microbial load $\left(\mathrm{cfu} \times 10^{5}\right)$ of broiler chickens fed probiotic and enzyme supplemented diets}

Result on microbial population on diets supplemented with probiotic and enzyme is presented in Table 4. Total heterotrophic counts of birds fed control diet $\left(61.92 \times 10^{5}\right.$ $\mathrm{cfu} / \mathrm{ml})$ and probiotic diet $\left(64.48 \times 10^{5} \mathrm{cfu} / \mathrm{ml}\right)$ were similar but significantly $(p<0.05)$ higher than the antibiotic $\left(45.16 \times 10^{5} \mathrm{cfu} / \mathrm{ml}\right)$, enzyme $\left(47.70 \times 10^{5} \mathrm{cfu} / \mathrm{ml}\right)$ and probiotic + enzyme $\left(47.06 \times 10^{5} \mathrm{cfu} / \mathrm{ml}\right)$ supplemented diets. The highest total Lactobacilli count $\left(12.78 \times 10^{5}\right.$ $\mathrm{cfu} / \mathrm{ml}$ ) was recorded in the mixture of probiotic + enzyme diet while least was observed in total Lactobacilli count of birds fed probiotic $\left(2.58 \times 10^{5} \mathrm{cfu} / \mathrm{ml}\right)$ diet and enzyme supplemented diet $\left(1.45 \times 10^{5} \mathrm{cfu} / \mathrm{ml}\right)$. Total coliform count of birds fed antibiotic diet was significantly $\left(14.12 \times 10^{5}\right.$ $\mathrm{cfu} / \mathrm{ml}$ ) lower than for those on other dietary treatments (basal diet: $27.24 \times 10^{5} \mathrm{cfu} / \mathrm{ml}$; probiotic: $29.44 \times 10^{5} \mathrm{cfu} / \mathrm{ml}$; enzyme: $23.50 \times 10^{5} \mathrm{cfu} / \mathrm{ml}$; probiotic + enzyme: $27.90 \times 10^{5}$ $\mathrm{cfu} / \mathrm{ml}$ respectively). Total Escherichia coli count was highest in birds fed antibiotic diet $\left(28.98 \times 10^{5} \mathrm{cfu} / \mathrm{ml}\right)$ while least was observed in birds fed mixture of probiotic + enzyme supplemented diet $\left(2.44 \times 10^{5} \mathrm{cfu} / \mathrm{ml}\right)$.

\section{Histopathology of ileum of birds fed probiotic and enzyme supplemented diets}

Plates 1 and 2 show photomicrographs of birds on basal diet (Treatment 1). lleum of birds fed probiotic diet showed sloughed mucosa layer and degenerated villi, the lamina proprial showed degenerated tissues with moderate infiltration of inflammatory cells.

Plates 3 and 4 show photomicrographs of birds on antibiotic diet (Treatment 2). lleum of birds placed on antibiotic diet showed normal mucosa layer with normal villi.

Plates 5 and 6 show photomicrographs of birds on probiotic diet (Treatment 3). Ileum of birds placed on probiotic diet showed normal lamina proprial, normal tissue and submucosal layer. 
Table 2. Gross composition ( $\mathrm{g} / \mathrm{kg}$ ) of diets supplemented with probiotic and enzyme (finisher phase).

\begin{tabular}{|c|c|c|c|c|c|}
\hline Ingredient & $\begin{array}{l}\text { Negative control } \\
\text { (NC) basal diet }\end{array}$ & $\begin{array}{l}\text { Positive control } \\
\text { (PC) antibiotic }\end{array}$ & $\begin{array}{c}\mathrm{NC}+ \\
\text { Probiotic }\end{array}$ & $\begin{array}{c}\mathrm{NC}+ \\
\text { Enzyme }\end{array}$ & $\begin{array}{c}\mathrm{NC}+\text { Enzyme + } \\
\text { Probiotic }\end{array}$ \\
\hline Corn & 661.00 & 652.00 & 651.00 & 655.00 & 650.00 \\
\hline Soyabean meal & 280.00 & 280.00 & 280.00 & 280.00 & 280.00 \\
\hline Fish meal & 25.00 & 25.00 & 25.00 & 25.00 & 25.00 \\
\hline Soya Oil & 8.00 & 8.00 & 8.00 & 8.00 & 8.00 \\
\hline Dicalcium phosphate & 16.00 & 16.00 & 16.00 & 16.00 & 16.00 \\
\hline Broiler Premix & 2.00 & 2.00 & 2.00 & 2.00 & 2.00 \\
\hline Limestone & 4.00 & 10.00 & 8.00 & 7.00 & 8.00 \\
\hline Methionine & 1.00 & 2.00 & 2.00 & 2.00 & 2.00 \\
\hline Lysine & 1.00 & 2.00 & 2.00 & 2.00 & 2.00 \\
\hline Table Salt & 2.00 & 2.00 & 2.00 & 2.00 & 2.00 \\
\hline Antibiotic & 0.00 & 1.00 & 0.00 & 0.00 & 0.00 \\
\hline Probiotic & 0.00 & 0.00 & 4.00 & 0.00 & 4.00 \\
\hline Enzyme & 0.00 & 0.00 & 0.00 & 1.00 & 1.00 \\
\hline Total & 1000.00 & 1000.00 & 1000.00 & 1000.00 & 1000.00 \\
\hline \multicolumn{6}{|c|}{ Calculated nutrient (g/kg) } \\
\hline Crude protein & 201.88 & 200.98 & 201.82 & 201.47 & 201.91 \\
\hline Energy ME, kcal/kg & 3164.57 & 3133.66 & 3130.2 & 3143.97 & 3126.80 \\
\hline Ether extract & 45.36 & 45.00 & 44.97 & 45.13 & 45.13 \\
\hline Crude fibre & 34.31 & 34.11 & 34.52 & 34.30 & 34.30 \\
\hline Calcium g/kg & 7.22 & 9.44 & 8.74 & 8.34 & 8.34 \\
\hline Total phosphorus & 7.01 & 6.99 & 7.00 & 6.99 & 6.99 \\
\hline Non-phytate P & 3.90 & 3.89 & 3.90 & 3.90 & 3.90 \\
\hline Ca:NPP & 1.85 & 2.42 & 2.23 & 2.13 & 2.13 \\
\hline
\end{tabular}

Supplied the following per $\mathrm{kg}$ diet: vitamin $\mathrm{A}, 12500 \mathrm{IU}$; vitamin $\mathrm{D}_{3}, 2500 \mathrm{IU}$; vitamin $\mathrm{E}, 40 \mathrm{mg}$; vitamin $\mathrm{K}_{3}$, 2mg; vitamin $\mathrm{B}_{1}$, 3mg; vitamin $\mathrm{B}_{2}, 5.5 \mathrm{mg}$; niacin, $55 \mathrm{mg}$; calcium panthotenate, $11.5 \mathrm{mg}$; vitamin $\mathrm{B}_{6}, 5 \mathrm{mg}$; vitamin $\mathrm{B} 12,0.025 \mathrm{mg}$; choline chloride, $500 \mathrm{mg}$; folic acid, 1mg; biotin, $0.08 \mathrm{mg}$; manganese, 120mg; Iron, 100mg; zinc, $80 \mathrm{mg}$; copper, $8.5 \mathrm{mg}$; iodine, $1.5 \mathrm{mg}$; cobalt, 0.3mg; selenium, 0.12mg; anti-oxidant, $120 \mathrm{mg}$.

Table 3. Performance indices of broiler chickens fed diets supplemented with probiotic and enzyme at starter (d 0-21) and finisher (d22-42) phases.

\begin{tabular}{|c|c|c|c|c|c|c|c|}
\hline Parameter & $\begin{array}{c}\text { Negative control } \\
\text { basal diet }\end{array}$ & $\begin{array}{l}\text { Positive control } \\
\text { antibiotic }\end{array}$ & Probiotic & Enzyme & $\begin{array}{c}\text { Probiotic + } \\
\text { Enzyme }\end{array}$ & SEM & $P$ value \\
\hline \multicolumn{8}{|l|}{ Starter phase } \\
\hline Initial weight (g/b) & 41.50 & 41.92 & 41.2 & 41.62 & 40.9 & 0.26 & 0.78 \\
\hline Final weight (g/b) & 590.10 & 597.12 & 564.66 & 528.12 & 545.18 & 10.15 & 0.19 \\
\hline Weight gain (g/b) & 548.60 & 555.20 & 523.46 & 486.50 & 504.28 & 10.12 & 0.20 \\
\hline feed intake (g/b) & 1286.1 & 1307.5 & 1482.7 & 1332.7 & 1474.7 & 47.53 & 0.54 \\
\hline Feed conversion ratio & 2.35 & 2.37 & 2.84 & 2.79 & 2.90 & 0.09 & 0.18 \\
\hline \multicolumn{8}{|l|}{ Finisher phase } \\
\hline Initial weight & 590.10 & 597.12 & 564.66 & 528.12 & 545.18 & 10.15 & 0.20 \\
\hline Final weight & 1668.66 & 1660.94 & 1564.20 & 1519.22 & 1507.66 & 24.37 & 0.140 \\
\hline
\end{tabular}


Table 4. Microbial load $\left(\mathrm{cfu} / \mathrm{ml} \times 10^{5}\right)$ of broiler chicken fed with diets supplemented with probiotic and enzyme.

\begin{tabular}{lccccccc}
\hline Parameter & $\begin{array}{c}\text { Negative control } \\
\text { basal diet }\end{array}$ & $\begin{array}{c}\text { Positive control } \\
\text { Antibiotic }\end{array}$ & Probiotic & Enzyme & $\begin{array}{c}\text { Probiotic } \\
\text { + Enzyme }\end{array}$ & SEM & P value \\
\hline THC & $61.92^{\mathrm{a}}$ & $45.16^{\mathrm{b}}$ & $64.48^{\mathrm{a}}$ & $47.70^{\mathrm{b}}$ & $47.06^{\mathrm{b}}$ & 1.70 & 0.0029 \\
TLC & $8.45^{\mathrm{b}}$ & $8.78^{\mathrm{b}}$ & $2.58^{\mathrm{c}}$ & $1.45^{\mathrm{c}}$ & $12.78^{\mathrm{a}}$ & 0.38 & 0.0001 \\
TCC & $27.24^{\mathrm{a}}$ & $14.12^{\mathrm{b}}$ & $29.44^{\mathrm{a}}$ & $23.50^{\mathrm{a}}$ & $27.90^{\mathrm{a}}$ & 1.61 & 0.0468 \\
TEC & $19.20^{\mathrm{c}}$ & $28.98^{\mathrm{a}}$ & $23.18^{\mathrm{b}}$ & $4.54^{\mathrm{d}}$ & $2.44^{\mathrm{e}}$ & 0.90 & 0.0001 \\
\hline
\end{tabular}

Means along the same row with similar superscripts $(P>0.05)$ are not significantly different. THC-Total Heterotrophic Count; TLC-Total Lactobacilli Count; TCC-Total Coliform Count; TEC-Total E. coli Count.
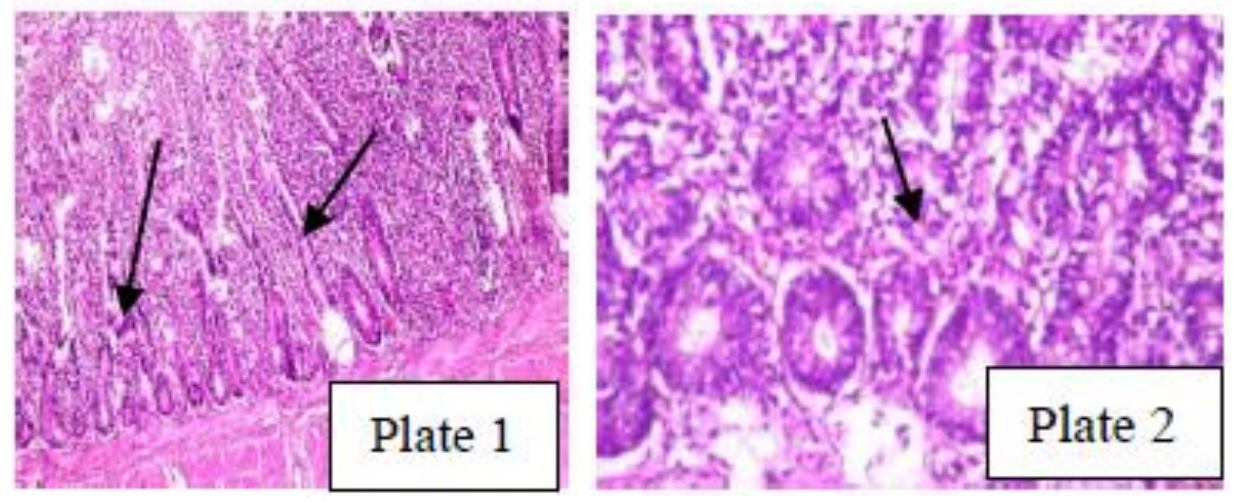

Plates 1 and 2. Photomicrographs of birds on basal diet (Treatment 1).
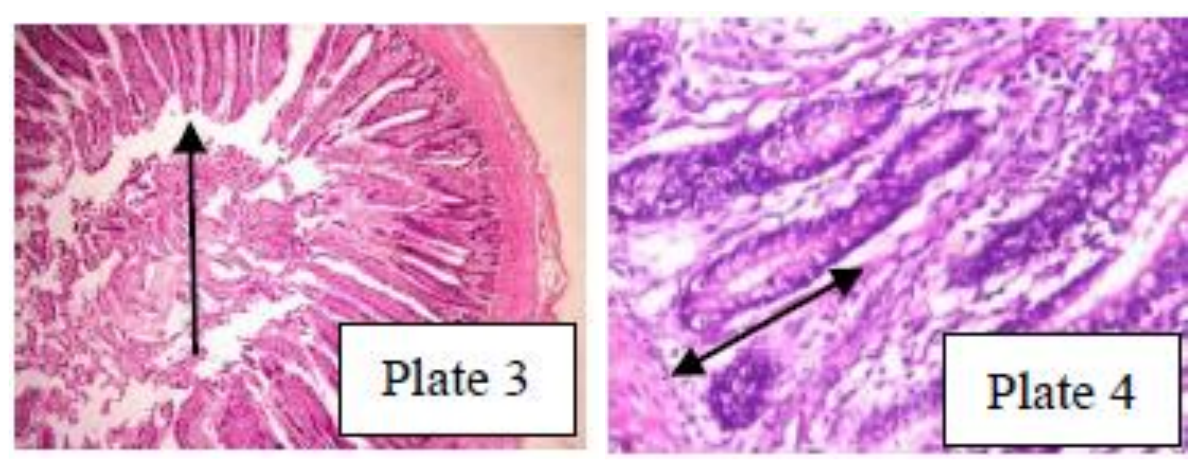

Plates 3 and 4. Photomicrographs of birds on antibiotic diet (Treatment 2).
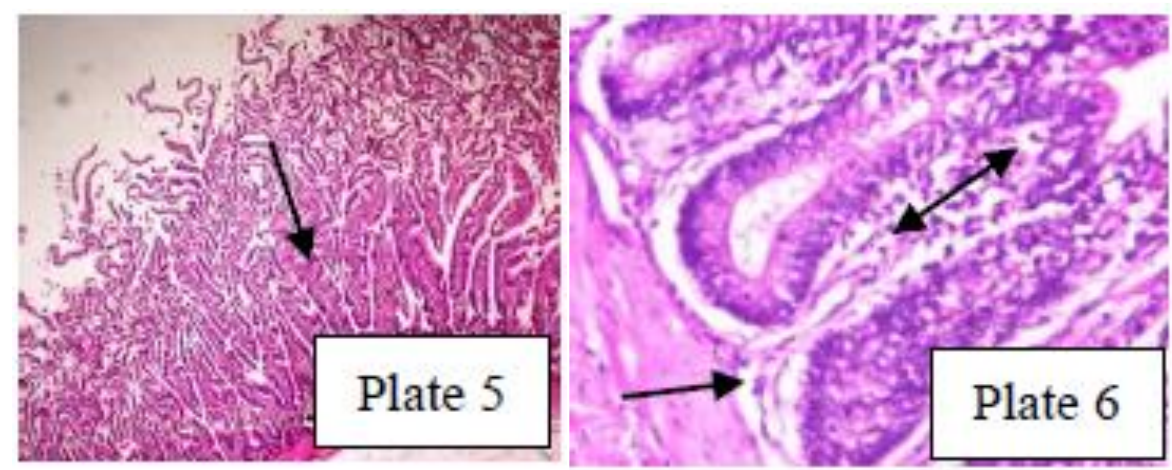

Plates 5 and 6. Photomicrographs of birds on probiotic diet (Treatment 3). 

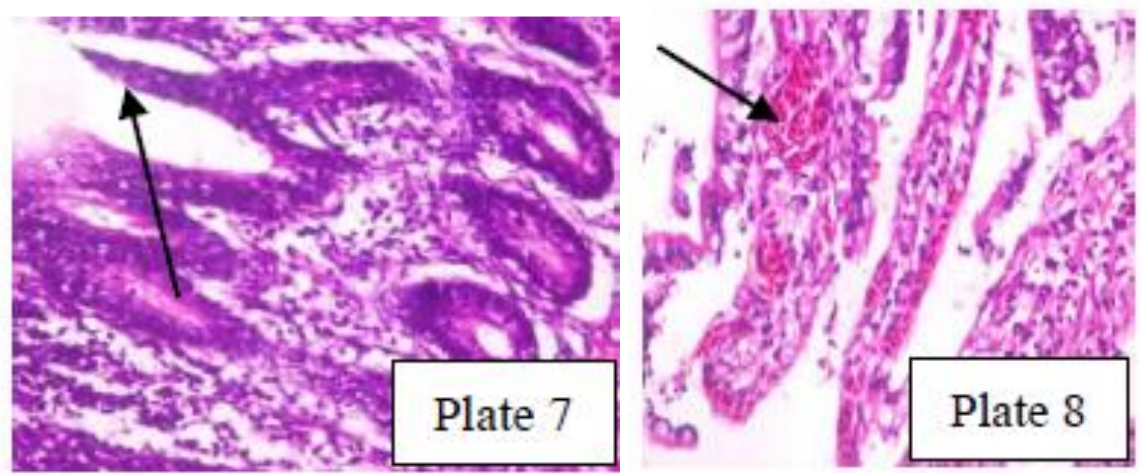

Plates 7 and 8. Photomicrographs of birds on enzyme diet (Treatment 4).
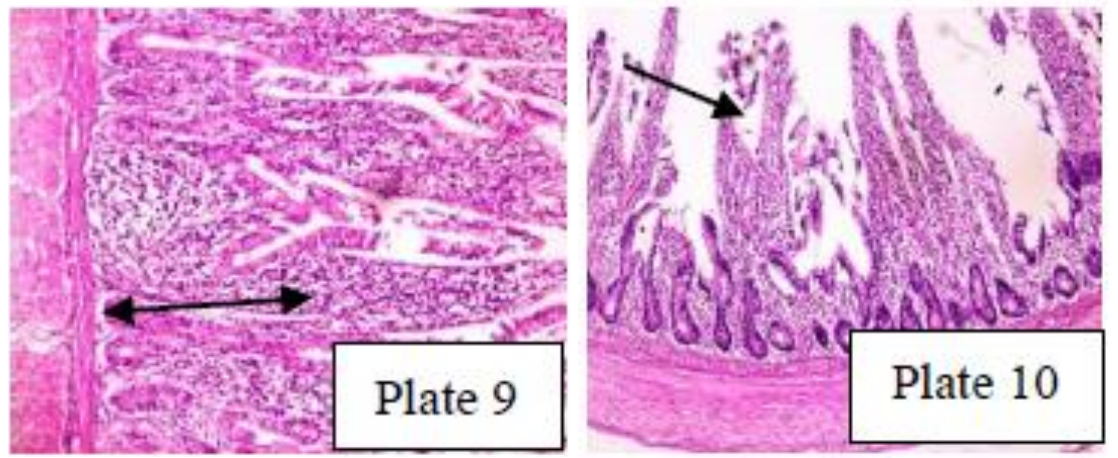

Plates 9 and 10. Photomicrographs of birds on probiotic + enzyme (Treatment 5).

Plates 7 and 8 show photomicrographs of birds on enzyme diet (Treatment 4). Ileum of bird placed on enzyme supplemented diet showing normal mucosa layer with normal villi (Plate 7) but Plate 8 showed mucosa layer with moderately hemorrhagic villi.

Plates 9 and 10 show photomicrographs of birds on probiotic plus enzyme (Treatment 5). Ileum of birds placed on probiotic + enzyme: showing normal mucosa layer with normal villi (Plate 9) but Plate 10 showed poorly preserved mucosa layer with mildly sloughed villi.

\section{DISCUSSION}

\section{Performance indices of birds fed probiotic and enzyme supplemented diets}

There were no remarkable differences observed in the feed intake, weight gain and feed conversion ratio of the birds on the experimental diets in both phases. These results corroborate the findings of Maiolino et al. (1992) who reported no observable effect of probiotic supplementation on performance of broilers. This was also supported by Agboola et al. (2014) who observed that the inclusion of probiotic and symbiotic in a corn-soyabean meal-based diet did not improve feed intake, feed conversion ratio and protein intake of turkey poults at the grower phase. In contrast, Miljkovic et al. (1997) asserted increased weight gain in birds upon feeding probiotic supplemented diet. According to Jin et al. (1998) and Patterson and Burkholder (2003), it was postulated that different results accrued in probiotic application to poultry diets probably depend on many factors, among which are species composition of probiotic, administration levels, application methods, overall diet composition, bird age and environmental factors. The result of this study is in agreement with observations of Loddi et al. (2000) and Willis and Reid (2008) who reported that supplementation of probiotics had no effect on the performance of broilers in any of the breeding phases. Fernandes et al. (2014) opined that birds fed alternative additives (prebiotic, probiotic, symbiotic or organic acid) had similar weight gain with those on antimicrobial product but were not different from birds on the control diet. Furthermore, Comert (2004) also reported that dietary mannan oligosaccharides and probiotic addition did not affect the feed intake of young turkeys from 0 to 8 weeks of age and Bronze turkeys from 7 to 21 weeks of age.

Contrary to the result of this study, Brenes et al. (1993) revealed that enzyme supplementation resulted in significant increase in body weights and feed conversion ratio in broiler chickens on barley-based diets up to six 
weeks. Also, Saleh et al. (2019) reported improved performance and nutrient digestibility in broiler chickens fed low-energy diets supplemented with mixture of dietary xylanase and arabinofuranosidase. According to Mehri et al. (2010), mannanase supplementation significantly reduced feed intake but did not influence body weight gain and feed conversion ratio in broiler chickens fed corn-soya diets. Similarly, dietary supplementation of enzyme cocktail of xylanase, amylase, and protease did not improve growth performance (weight gain and feed efficiency) in broiler chickens fed corn-soyabean diets for 21 days (Tiwari et al., 2010). Rexen (1981) however averred that effect of enzyme supplementation is more pronounced when the feed contains ingredients that are less-digestible. This statement was corroborated by Cozannet et al. (2017) and Aftab and Bedford (2018) who opined that diet composition is a key factor affecting the response to enzyme supplementation in poultry. This could be the reason why effect of enzyme supplementation was not pronounced on growth performance, in this study, because corn-soyabean meal diet was fed to the birds.

\section{Microbial population of birds fed probiotic and enzyme supplemented diets}

One benefit of using probiotics is to allow a numeric competitive advantage for beneficial intestinal microbes over the pathogenic microbes (Higgins et al., 2010). The result of the present study appears inconsistent. Birds on mixed probiotic-enzyme supplemented diets had significantly higher total Lactobacillus content compared to those on basal and antibiotic diets. It is however surprising that birds on probiotic and enzyme supplemented diets had very low counts of lactobacillus. Contrary to above finding, Biswas et al. (2018) reported an increase in the ileal and caecal Lactobacilli counts on days 21 and 42 in broiler chickens fed probiotic supplemented diets. In the present result, supplementation of mixed probiotic-enzyme and individual enzyme resulted in a lowered total $E$. coli count in comparison to the un-supplemented control. In agreement with the present finding, Mountzouris et al. (2010) reported reduction in the number of Enterobacteria in broiler chickens fed with a probiotic strain of $L$. reuteri. When Salim et al. (2013) fed broiler chicken a dietary supplement of directly-fed microbials, caeca lactobacillus content remained similar with birds on control (corn-soya) diet at 35 days, while cecal Escherichia coli content significantly decreased in broiler chickens fed directly-fed microbials. Mountzouris et al. (2009) showed that probiotic is effective at reducing the number of Salmonella enteritidis in broiler chickens. Rolfe (2000) suggested that probiotics exert their effects through competitive exclusion for adherence site on the gut, and for nutrients. This mechanism might be responsible for the increased number of lactobacillus and simultaneous lowering of $E$. coli count in the gut of birds fed mixed enzyme-probiotic dietary supplement in the present study.
Gut histopathological measurement of broiler chickens fed probiotic and enzyme supplemented diets

The efficiency at which digested nutrient are absorbed can be assessed using the histopathology of the intestine because it is the main site for nutrient absorption. This effect is determined by gross morphological features such as length and cross-sectional area of the duodenal, jejunal, ileal and caecal segments and by finer morphological features such as villus height and crypt depth as indicators of surface area of epithelium (Jin et al., 1998). Mucosa status and their microscopic structure may be good indicator of the response of intestinal tract to active substances present in feeds and in intestinal content (Viveros et al., 2011). In this study, histopathological changes observed in birds on negative control (basal diet) included sloughed mucosa layer and degenerated villi while other treatments showed normal submucosal and mucosa layers with normal villi and lamina propria showed normal tissues except for enzyme supplemented diet that showed mucosa layer with moderately hemorrhagic villi. Similar to the findings of Agboola et al. (2019), histopathological observation of broiler chickens on the control diet showed villi and hepatocellular atrophy but no lesions were found in the ileum of those on antibiotic supplemented diet. However, clinical symptoms ranging from villi atrophy, necrosis of the villi, loss of enterocyte, hepatocellular atrophy and focus of lymphoid aggregate in parenchyma of liver were observed in birds that received butyric acid supplemented diets. Unlike the pathological changes observed in the liver tissues of birds fed butyric supplemented diets, in this study, there was improved gut integrity because competitive exclusion of pathogenic bacteria that led to reduction in total Escherichia coli count with resultant increase in total Lactobacilli count was evident in birds fed with probiotic + enzyme supplemented diet. This was a reflection of improved submucosal and mucosa layers with normal villi which resulted in enhanced absorptive activity.

\section{Conclusion}

In this study, supplementation of diets with probiotic, enzyme or their combinations did not have remarkable influence on the growth response of broiler chicken. However, gut intergrity of birds was improved. Mixture of $0.4 \%$ probiotic $+0.1 \%$ enzyme is recommended to serve as subtitute to antibiotic growth promoter in poultry nutrition.

\section{CONFLICT OF INTEREST}

The authors declare that they have no conflict of interest.

\section{REFERENCES}

Aftab, U., \& Bedford, M. R. (2018). The use of NSP enzymes in 
poultry nutrition: myths and realities. World's Poultry Science Journal, 74(2), 277-286.

Agboola, A. F., Omidiwura, B. R. O., Odu, O., Adeyemi, W. T., Suberu, S. A., Aroniyo, I., \& lyayi, E. A. (2014). Influence of dietary supplementation of probiotics and symbiotics on growth performance, nutrient digestibility and organ weights in turkey poults. Ibadan Journal of Agricultural Research, 10(1), 1-12.

Agboola, A. F., Omidiwura, B. R. O., Ahmed, R. O., \& Ayoola, O. D. (2019). Influence of Butyric Acid Supplemented Diets on Growth Response, Precaecal Nutrient Digestibility, Gut Morphology and Histopathological Measurements in Broiler Chickens. Nigerian Journal of Animal Production, 46 (4), 117133

AOAC (2000). Official methods of analysis. 17th edition, The association of official analytical chemists, Gaithersburg, MD, USA.

Bidarkar, V. K., Swain, P. S., Ray, S., \& Dominic, G. (2014). Probiotics. Potential alternative to antibiotics in ruminant feeding. Trend in Veterinary and Animal Sciences, 1(1), 1-4.

Biswas, A., Junaid, N., Kumawat, M., Qureshi, S., \& Mandal, A.B. (2018). Influence of dietary supplementation of probiotics on intestinal histo-morphometry, blood chemistry and gut health status of broiler chickens. South African Journal of Animal Science, 48(5), 965-976.

Brenes, A., Smith, M., Guenter, W., \& Marquardt, R. R. (1993). Effect of enzyme supplementation on the performance and digestive tract size of broiler chickens fed wheat-and barleybased diets. Poultry Science, 72(9), 1731-1739.

Comert, N. (2004). The effects of avilamycin, bio-moss, cylactin and yucca schidigera extract added to the cornsoybean meal based diets on fattening performance, slaughter results and some blood and intestinal parameters of male broiler turkey. Ankara University Graduate School of Natural Applied Sciences. PhD thesis. Department of Animal Sciences. Pp 57.

Cozannet, P., Kidd, M. T., Neto, R. M., \& Geraert, P. A. (2017). Next-generation non-starch polysaccharide-degrading, multicarbohydrase complex rich in xylanase and arabinofuranosidase to enhance broiler feed digestibility. Poultry Science, 96(8), 2743-2750.

Engberg, R. M., Hedemann, M. S., Steenfeldt, S., \& Jensen, B. B. (2004). Influence of whole wheat and xylanase on broiler performance and microbial composition and activity in the digestive tract. Poultry Science, 83(6), 925-938.

Fernandes, B. C. S., Martins, M. R. F. B., Mendes, A. A., Milbradt, E. L., Sanfelice, C., Martins, B. B., Aguiar, E. F., \& Bresne, C. (2014). Intestinal integrity and performance of broiler chickens fed a probiotic, a prebiotic, or an organic acid. Brazilian Journal of Poultry Science, 16(4), 417-424.

Fuller, R. (1989). Probiotics in man and animals. A review. Journal of Applied Bacteriology, 66(5), 365-378.

Gheisar, M. M., \& Kim, I. H. (2017). Phytobiotics in poultry and swine nutrition - a review. Italian Journal of Animal Science, 17(1), 92-99.

Heidarpour, F., Mohammadabadi, M. R., Zaidul, I. S. M., Maherani, B., Saari, N., Hamid, A. A., Abas, F., Manap, M. Y. A., \& Mozafari, M. R. (2011). Use of prebiotics in oral delivery of bioactive compounds: a nanotechnology perspective. Pharmazie, 66 (5), 319-324.

Higgins, J. P., Higgins, S. E., Wolfenden, A. D., Henderson, S. N., Torres-Rodriguez, A., Vicente, J. L., Hargis, B. M., \& Tellez, G. (2010). Effect of lactic acid bacteria probiotic culture treatment timing on Salmonella enteritidis in neonatal broilers. Poultry Science, 89(2), 243-247.
Holdeman, L. V., Cato, E. P., \& Moore, E. C. (1977). Anaerobic laboratory manual, Virginia Polytechnique Institute and State University, Blacksburg, VA.

Hosseini, S. M., Nazarizadeh, H., Ahani, S., \& Vakili Azghandi, M. (2016). Effects of mannan oligosaccharide and Curcuma xanthorrhiza essential oil on the intestinal morphology and stress indicators of broilers subjected to cyclic heat stress. Archives Animal Breeding, 59(2), 285-291.

lji, P. A., Saki, A., \& Tivey, D. R. (2001). Body and intestinal growth of broiler chicks on a commercial starter diet. 1. Intestinal weight and mucosal development. British Poultry Science, 42(4), 505-513.

Jin, L. Z., Ho, Y. W., Abdullah, N., \& Jalaludin, S. (1998). Growth performance, intestinal microbial populations, and serum cholesterol of broilers fed diets containing Lactobacillus cultures. Poultry Science, 77(9), 1259-1265.

Khattak, F. M., Pasha, T. N., Hayat, Z. and Mahmud, A. (2006). Enzymes in poultry nutrition. Journal of Animal and Plant Sciences, 16(1-2), 1-7.

Kurekci, C., Al Jassim, R., Hassan, E., Bishop-Hurley, S. L., Padmanabha, J., \& McSweeney, C. S. (2014). Effects of feeding plant-derived agents on the colonization of Campylobacter jejuni in broiler chickens. Poultry Science, 93(9), 2337-2346

Loddi, M. M., Gonzales, E., Takita, T. S., Mendes, A. A., \& Roça, R. D. O. (2000). Effect of the use of probiotic and antibiotic on the performance, yield and carcass quality of broilers. Revista Brasileira de Zootecnia, 29(4), 1124-1131.

Maiolino, R., Fioretti, A., Menna, L. F, \& Meo, C. (1992). Research on the efficiency of probiotics in diets for broiler chickens. Nutrition Abstracts and Reviews Series B, 62, 482.

Markazi, A. D., Luoma, A., Shanmugasundaram, R., Murugesan, R., Mohnl, M., \& Selvaraj, R. (2019). Effect of acidifier product supplementation in laying hens challenged with Salmonella. Journal of Applied Poultry Research, 28(4), 919-929.

Mathur, S., \& Singh, R. (2005). Antibiotic resistance in food lactic acid bacteria-a review. International journal of food microbiology, 105(3), 281-295.

Mehri, M., Adibmoradi, M., Samie, A., \& Shivazad, M. (2010). Effects of $\beta$-Mannanase on broiler performance, gut morphology and immune system. African Journal of Biotechnology, 9(37), 6221-6228.

Miljkovic, B., Ilic, Z., Strizak, D.M., Jakic, D., \& Rajic I. (1997). Acid-pak 4-way in feeding broilers. Zivinarstvo, 32, 7-8.

Mountzouris, K., Balaskas, C., Xanthakos, I., \& Tzivinikou, A. (2009). Effects of a multi-species probiotic on biomarkers of competitive exclusion efficacy in broilers challenged with Salmonella enteritidis. British Poultry Science, 50(4), 467-78.

Mountzouris, K.C., Tsitrsikos, P., Palamidi, I., Arvaniti, A., Mohnl, M., Schatzmayr, G., \& Fegeros, K. (2010). Effects of probiotic inclusion levels in broiler nutrition on growth performance, nutrient digestibility, plasma immunoglobulins, and cecal microflora composition. Poultry Science, 89(1), 58-67.

NAFDAC (2018). National Agency for Food and Drug Administration and Control (Press release on antimicrobial resistance. July 25, 2018.

NRC (1994). National Research Council, Nutrient Requirements of Poultry. 9th Revised Edition. National Academy Press, Washington DC.

Patterson, J. A., \& Burkholder. K. M. (2003). Application of prebiotics and probiotics in poultry production. Poultry Science, 82(4), 627-631.

Rexen, B. (1981). Use of enzymes for improvement of feed. Animal Feed Science and Technology, 6, 105-114. 
Rolfe, R. D. (2000). The role of probiotic cultures on gastrointestinal health. Journal of Nutrition,130(2S Suppl), 396S-402S.

Saleh, A. A., Kirrella, A. A., Abdo, S. E., Mousa, M. M., Badwi, N. A., Ebeid, T. A., Nada, A. L., \& Mohamed, M. A. (2019). Effects of dietary xylanase and arabinofuranosidase combination on the growth performance, lipid peroxidation, blood constituents, and immune response of broilers fed low-energy diets. Animals, 9(7), 1-12.

Salim, H.M., Kang, H. K., Akter, N., Kim, D. W., Kim, J. H., Kim, M. J., Na, J. C., Jong, H. B., Choi, H. C., Suh, O. S., \& Kim, W. K. (2013). Supplementation of direct-fed microbials as an alternative to antibiotic on growth performance, immune response, cecal microbial population, and ileal morphology of broiler chickens. Poultry Science, 92(8), 2084-2090.

SAS (2012). Statistical Analysis System, User's Guide. Statistical. Version 9.1th ed. SAS. Inst. Inc. Cary. N.C. USA.
Stanton, T. B. (2013). A call for antibiotic alternatives research. Trends in Microbiology, 21(3), 111-113.

Tiwari, S. P., Gendley, M. K., Pathak, A. K., \& Gupta, R. (2010). Influence of an enzyme cocktail and phytase individually or in combination in Ven Cobb broiler chickens. British Poultry Science, 51(1), 92-100.

Viveros, A., Chamorro, S., Pizarro, M., Arija, I., Centeno, C., \& Brenes, A. (2011). Effects of dietary polyphenol-rich grape products on intestinal microflora and gut morphology in broiler chicks. Poultry Science, 90(3), 566-578.

Willis, W. L., \& Reid, L. (2008). Investigating the effects of dietary probiotic feeding regimens on broiler chicken production and Campylobacter jejuni presence. Poultry Science, 87(4), 606611. 